\title{
Alternatif Strategi Bauran Pemasaran 7P Museum Batik Yogyakarta
}

\author{
Ahmadintya Anggit Hanggraito ${ }^{*}$, Ahmad Sidiq Wiratama², Rahma Amalia Saifuddien ${ }^{3}$ \\ Magister Kajian Pariwisata Universitas Gadjah Mada123 \\ Email: datamasanggit@gmail.com¹, ahmadsidiqwiratama@gmail.com², \\ rahmaamaliasaifuddien@gmail.com ${ }^{3}$
}

\begin{abstract}
Yogyakarta Batik Museum is one of the tourist destinations where as batik as major attraction. The museum is not only being a place of batik storage collections, but also offer hotels, batik shops and training of classic batik production. This study aims to provide Alternatives on marketing strategies through 7P marketing mix analysis in Yogyakarta Batik Museum. The type of research used is descriptive qualitative. Primary and secondary data are used in analyzing the 7P marketing mix at the Yogyakarta Batik Museum. The data was obtained that concerns on products, prices, places, promotions, physical evidence, people and processes in implementation the marketing strategy of the Yogyakarta Batik Museum. The results of this study are recommended alternative marketing strategies for the Yogyakarta Batik Museum. These alternative strategies are Strengthening historical and cultural values as the identity of products from batik in Yogyakarta batik museum, Differentiation of ticketing prices for tourists, Optimization of online strength through social media, and Optimization of tasks and jobs in Human Resources.
\end{abstract}

Keywords: Museum, Batik, Marketing Mix, Culture

\begin{abstract}
Abstrak
Museum Batik Yogyakarta merupakan salah satu destinasi wisata dimana batik sebagai atraksi utama. Museum ini tidak hanya menyimpan koleksi batik, namun juga menawarkan hotel, toko batik dan pelatihan pembuatan batik klasik. Penelitian ini bertujuan untuk memberikan strategi alternatif pemasaran melalui analisis bauran pemasaran 7P di Museum Batik Yogyakarta. Jenis penelitian yang digunakan adalah deskriptif kualitatif. Data primer dan sekunder digunakan untuk menganalisis bauran pemasaran 7P di Museum Batik yogyakarta. Data yang diperoleh menyangkut produk, harga, tempat, promosi, bukti fisik, orang dan proses dalam implementasi strategi pemasaran Museum Batik Yogyakarta. Hasil penelitian ini berupa strategi alternatif pemasaran yang direkomendasikan untuk Museum Batik Yogyakarta. Strategi alternatif tersebut adalah Penguatan nilai sejarah dan budaya sebagai identitas produk dari batik di museum batik Yogyakarta, Differensiasi harga pada tiket masuk untuk wisatawan, Optimalisasi kekuatan daring melalui media sosiai, dan Optimalisasi tugas dan pekerjaan pada Sumber daya Manusia.
\end{abstract}

Kata Kunci: Museum, Batik, Bauran Pemasaran, Budaya

\section{A. PENDAHULUAN}

Pada umumnya, kegiatan museum menghubungkan stakeholder lain dalam industri kreatif dan juga sektor lain dalam menopang ekonomi (Kamal-Chaoui, 2019). Hal ini menunjukkan bahwa, Museum menjadi salah satu alternatif destinasi yang memiliki produk unik dan menghadirkan pengalaman lebih pada wisatawan. Dampak dari adanya museum atau galeri terhadap perubahan ekonomi lokal akan menghasilkan pekerjaan, daya beli pengunjung, dan kesejahteraan yang lebih dirasakan (Travers \& Glaister, 2004). Menurut Peraturan Pemerintah (PP) No. 19 Tahun 1995, Museum adalah lembaga, tempat penyimpanan, perawatan, pengamanan, dan pemanfaatan benda bukti materil hasil budaya manusia, alam dan lingkungannya guna menunjang upaya perlindungan dan pelestarian kekayaan budaya bangsa. Hal ini menjelaskan bahwa, Museum sebagai destinasi yang melestarikan produk budaya masyarakat dapat menghasilkan nilai ekonomi bagi sekitarnya. 
Gambar 1. Grafik Jumlah Museum Tiap Provinsi tahun 2019

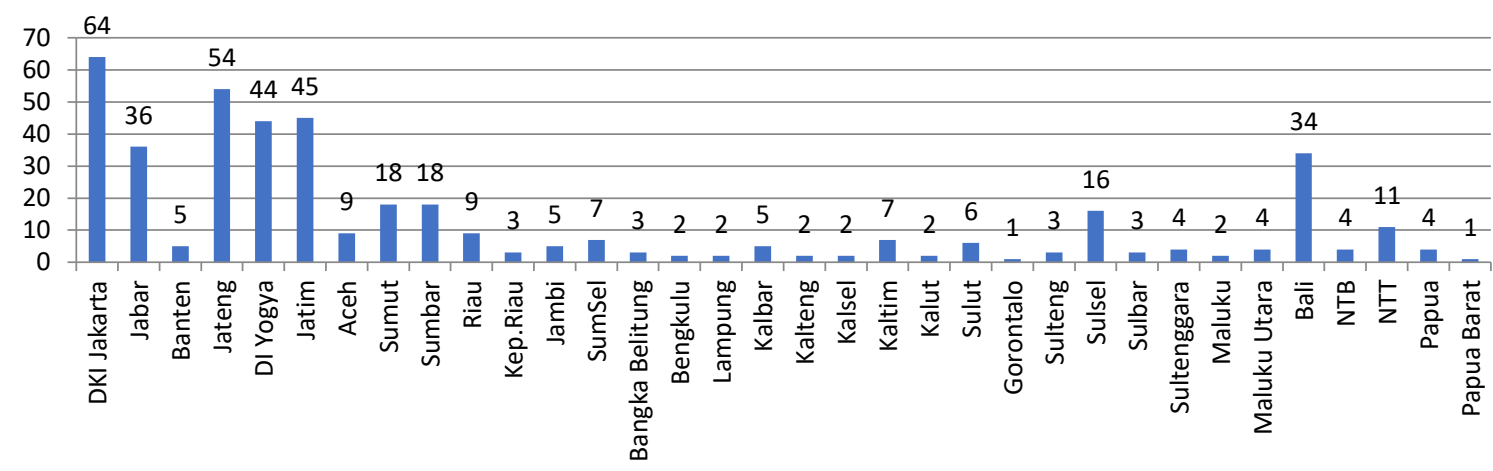

Sumber: Kementerian Pendidikan dan Kebudayaan, 2019

Gambar 1 menunjukkan bahwa, salah satu provinsi yang memiliki jumlah museum yang besar adalah Daerah Istimewa Yogyakarta, yakni sebanyak 44 destinasi museum (10.11\%). Jumlah kompetitif ini mengacu pada Daerah Istimewa Yogyakarta sebagai salah satu provinsi yang memiliki kekayaan budaya yang masih terjaga. Selain itu, dalam Wardiyanta, Sudarmadji, dan Nopirin (2016) dipaparkan bahwa, Daerah Istimewa Yogyakarta memiliki potensi daya tarik wisata yang kuat, diantaranya 1) memiliki objek wisata yang sangat beragam, 2) memiliki beragam kerajinan yang dapat dijadikan cinderamata, 3) memiliki sumber daya manusia berkualitas, dan 4) industri kreatif yang menjadi pendukung pariwisata berkembang dengan baik. Oleh karena itu, terdapat keberagaman museum di Daerah Istimewa Yogyakarta yang memiliki berbagai keunikan tersendiri dalam menyajikan daya tarik wisata.

Daerah Istimewa Yogyakarta memiliki berbagai macam museum yang mengusung budaya sebagai atraksi utama di Yogyakarta. Museum yang dimaksud antara lain seperti, Museum Sasonobudoyo, Museum Ulen sentalu, Museum Wayang, dan Museum Batik Yogyakarta. Salah satu destinasi yang menampilkan budaya secara komprehensif adalah Museum Batik Yogyakarta. Destinasi ini merupakan museum non pemerintah yang berdiri atas inisiatif Hadi Nugroho dan istrinya, Dewi Sukaningsih, didukung oleh para sahabat dan keluarga besar mereka (Museum Batik, 2020). Museum ini didirikan akibat dari kegelisahan dari Bapak Hadi Nugroho akan dinamika yang terjadi di industri batik pada tahun 1960an. Hal ini terkait dengan munculnya berbagai gempuran teknik printing dalam industri tekstil yang memangkas banyak kaidah dalam seni membatik tradisional. Destinasi tersebut resmi mendapatkan nomer induk museum, 09/I.13.XVI/II.2/77/01 pada tahun 2001. Kemudian, untuk akte Museum Batik Yogyakarta telah tercatat nomer 22 yang dikeluarkan pada tahun 1977 dan diperbaharui pada tahun 2014.

Sebagai sebuah destinasi edukasi budaya resmi, Museum Batik Yogyakarta juga mengembangkan klinik perawatan dan konservasi batik yang merekam jejak langkah proses batik dan ragam motifnya. Batik sendiri telah diakui secara internasional. Pada tanggal 2 Oktober 2009, yakni UNESCO (United Nation Educational, Scientific and Cultural Organization) menetapkan Batik Indonesia sebagai sebuah keseluruhan teknik, teknologi, pengembangan motif dan budaya yang terkait dengan batik tersebut sebagai karya agung warisan kemanusiaan untuk budaya lisan dan non bendawi (Masterpiece of The Oral and Intangible Heritage of Humanity) yaitu pengakuan internasional bahwa batik Indonesia adalah bagian kekayaan peradaban manusia (Karimah, Ernawati, \& Andreswari, 2015). Secara umum, Batik dibuat dengan tenaga manusia dan mempunyai makna pada setiap motifnya (Sahidah \& Habsari, 2018; Sara, Ernawati, \& Johar, 2019). Hal ini menunjukkan bahwa batik telah menjadi bagian dari produk dan jasa yang ditawarkan sebagai atraksi utama di Museum Batik Yogyakarta. Selain itu, museum ini tidak 
hanya menyimpan koleksi batik, namun juga menyediakan hotel dan toko batik dan suvenir yang lengkap (Muftisany, 2012). Hal ini menunjukkan terdapat keunikan tersendiri di dalam pengelolaan produk di museum batik Yogyakarta.

Di era pengelolaan destinasi wisata yang semakin kompetitif, dibutuhkan strategi pemasaran yang efisien dan tepat guna. Hal tersebut bukan hanya bertujuan untuk mengenalkan dan menjual produk. Namun, juga sebagai alat untuk menjaga keberlanjutan produk atau DTW (Hanggraito dan Sanjiwani, 2020). Secara teoritis, Pemasaran menurut American Marketing Association (AMA) adalah metode untuk menggeneralisasikan, mendistribusikan, mendukung dan memberi harga produk, layanan, dan perencanaan untuk promosi yang ramah pelanggan dan membangun dan membuat interaksi positif yang berkelanjutan dengan para pemangku kepentingan dalam lingkungan yang dinamis (Mudzanani, 2017; Sadq, Othman, \& Khorsheed, 2019) Dalam kepariwisataan, pemasaran pariwisata didefinisikan sebagai proses dimana kebutuhan wisatawan dapat diseimbangkan dengan tujuan organisasi wisatawan atau wilayah (Kotler \& Amstrong, 2007). Oleh karena itu, strategi pemasaran Museum Batik Yogyakarta yang optimal diharapkan dapat memaksimalkan keberlanjutan museum dan batik itu sendiri ditengah kedinamisan budaya yang ada di DI Yogyakarta.

\section{Gambar 2. Grafik Kunjungan Wisatawan tahun 2018-2019}

tahun 2018

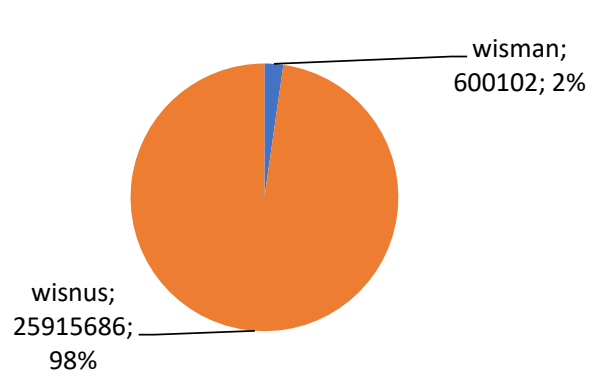

tahun 2019

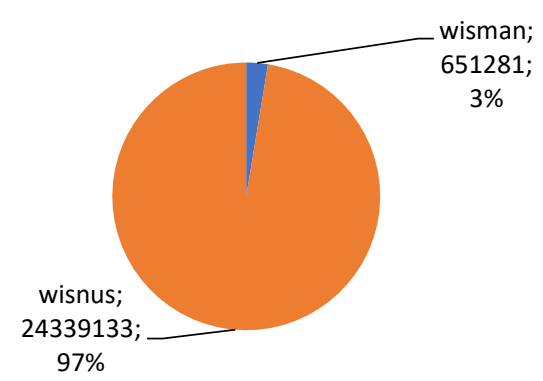

Sumber: BPS Provinsi Daerah Istimewa Yogyakarta, 2020

Gambar 2 menjelaskan bahwa, pada kisaran tahun 2018 hingga 2019 terjadi kontradiksi angka kujungan wisatawan di DI Yogyakarta. Secara angka, kunjungan wisatawan di DI Yogyakarta menunjukkan bahwa jumlah kunjungan wisatawan domestik turun dari 25.915 .686 orang menjadi 24.339.133 orang, atau sebanyak 1.576 .553 orang (turun $6.08 \%$ ). Sedangkan, untuk wisatawan mancanegara naik dari 600.102 orang menjadi 651.281 orang atau sebanyak 51.179 orang (naik 8.52 \%). Hal ini menunjukkan ada peluang besar bagi para pengelola untuk memaksimalkan strategi pemasaran dari destinasi wisatanya. Sebagai contuh terkait kunjungan wisatawan minat khusus. Segmen wisatawan minat khusus berpeluang untuk dijadikan salah satu segmen yang menunjang keberlanjutan dari sebuah destinasi seperti museum.

Keberlanjutan sebuah destinasi wisata dapat dicapai melalui sebuah keunggulan kompetitif sebuah destinasi wisata, seperti museum. Keunggulan kompetitif yang berkelanjutan dicapai melalui bauran pemasaran 7P (Abubakar, dkk., 2015). Strategi pemasaran terkait dengan penciptaan dari bauran pemasaran yang memungkinkan sebuah bisnis untuk mencapai tujuannya dalam pasar yang ditargetkan (Agic, Cinjarevic, Kurtovic, \& Cicic, 2016). Meng dan Chatwin, dalam Oematan (2017) menjelaskan, dalam strategi e-marketing, didasarkan dan dibangun atas 4P tradisional (product, price, promotion, dan place) yang membentuk bauran pemasaran klasik. Adanya perilaku konsumen yang berubah dewasa ini, bauran pemasaran tidak hanya berfokus dengan 4P tetapi juga dikembangkan ke 7P (Harrington, Ottenbacher, \& Fauser, 2017). Hal ini dipertegas melalui tujuh bauran yang dijabarkan melalui product, 
price, place, promotion, people, physical evidence dan process (Prapannetivuth, 2015). Oleh karena itu, analisis mengenai bauran pemasaran 7P diharapkan dapat memunculkan alternatif strategi yang tepat. Sehingga dapat meningkatkan keberlanjutan museum itu sendiri.

Strategi alternatif pemasaran yang tepat menjadi tahapan penting dalam pembangunan berkelanjutan dari Museum Batik Yogyakarta di masa yang akan datang. Hal ini selaras dengan Asmara (2019) yang menjelaskan bahwa, Keberadaan musem dalam dunia pendidikan begitu dibutuhkan, termasuk dalam pembelajaran sejarah. Selain itu, kerangka kerja bauran pemasaran digunakan untuk memandu museum tentang cara mengemas dan menjual proposisi nilainya lebih efektif (Mudzanani, 2017). Berdasarkan urgensitas tersebut, diperlukan analisis terhadap Bauran Pemasaran dari Museum Batik Yogyakarta. Sehingga, tujuan dari penelitian ini memberikan strategi alternatif pemasaran yang tepat melalui analisis bauran pemasaran 7P dari Museum Batik Yogyakarta.

\section{B. METODE PENELITIAN}

Penelitian ini merupakan penilitian deskriptif dengan pendekatan kualitatif. Penelitian deskriptif merupakan suatu penelitian yang bertujuan untuk menggambarkan sesuatu yang berlangsung pada saat penelitian dilakukan dan memeriksa sebab-sebab dari suatu gejala tertentu (Abdullah, 2015). Penelitian ini terdiri atas penggunaan data primer dan sekunder. Data primer didapatkan melalui wawancara indepth terhadap pengelola dan pemandu secara langsung, observasi langsung di Museum Batik Yogyakarta di tahun 2018. Data sekunder didapatkan melalui studi literatur. Dari hasil pengumpulan data mengenai strategi pemasaran yang dijalankan oleh museum kemudian, dilakukan analisis terkait bauran pemasaran 7P dari Museum Batik Yogyakarta. Analisa data dalam pendekatan kualitatif menurut Bogdan dan Bikler (1982) merupakan upaya yang dilakukan dengan jalan bekerja dengan data, mengorganisasikan data, memilih-milihnya menjadi satuan yang dapat dikelola, mensistensiskannya, mencari dan menemukan pola, menemukan apa yang penting dan yang dipelajari, dan memutuskan apa yang dapat diceritakan kepada orang lain.

\section{Gambar 3. Bagan Metode Analisa Data}

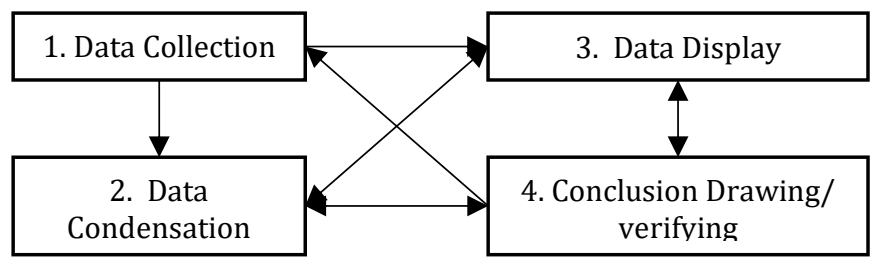

Sumber: Miles, Huberman, dan Saldana (2014)

Mengacu Gambar 3, Miles, Huberman (1992), terdapat beberapa tahapan yang menjelaskan alur pada metode analisa data. Tahapan tersebut adalah pengumpulan data, Kondensi Data, Penyajian Data, dan Penarikan kesimpulan/verifikasi.

Pada tahapan awal, Penulis melakukan pengumpulan data penelitian berdasarkan pada hasil wawancara in-depth, observasi langsung dan partisipan, serta studi literature. Kedua, Kondensi Data hasil penelitian. kondensasi data terkait pada proses menyeleksi, memfokuskan, menyederhanakan, mengabstraksi dan mentransformasi data yang di lapangan maupun transkrip (Miles \& Huberman, 1992). Dalam hal ini terkait temuan yang terkait pada Museum Batik Yogyakarta. Ketiga, Penulis menyajikan data. Penyajian data Penyajian data merupakan sebuah pengorganisasian, penyatuan, dan informasi yang disimpulkan (Miles \& Huberman, 1992). Dalam tahap ini diperlukan analisis yang mendalam. Keempat, Penulis menarik kesimpulan atau memverifikasi data. Menurut Sugiyono (2008), 
Kesimpulan dapat berupa deskripsi atau gambaran suatu obyek yang sebelumnya masih remangremang atau gelap sehingga setelah diteliti menjadi jelas, dapat berupa hubungan kausal atau interaktif, hipotesis atau teori.

Semua data diklasifikasikan sehingga dapat ditarik kesimpulan secara umum. Simpulan tersebut meliputi aspek yang terkait dengan 7 P. Setelah disimpulkan, analisis data pada tahap awal sampai semua data kompleks. Kesimpulan dari analisis data dijadikan bahan untuk merumuslan strategi alternatif pemasaran yang direkomendasikan untuk Museum Batik Yogyakarta.

\section{HASIL DAN ANALISIS}

Museum Batik Yogyakarta berlokasi di Jalan Dr Sutomo No. 13 A, Bausasran, Danurejan, Bausasran, Danurejan, Kota Yogyakarta, Daerah Istimewa Yogyakarta. Selain mempertunjukkan dan menjual berbagai batik khas Solo dan Yogyakarta serta berbagai khas batik lainnya, terdapat atraksi atau produk lain di dalam museum. Museum Batik Yogyakarta menyediakan jasa pelatihan pembuatan batik tulis maupun batik cap dengan harga pelatihan yang bervariasi. Terkait pelatihan pembuatan batik tulis ini sesuai dengan visi dan misi museum batik yogyakarta ini yakni, untuk melestarikan teknik dan pengetahuan tentang batik, serta mendokumentasikan motif-motif batik yang ada.

Terkait kunjungan wisatwan penelitian ini ditunjukkan data mengenai semester awal tahun 2018. Berikut grafiknya:

\section{Gambar 4. Grafik Kunjungan wisatawan Museum Batik Yogyakarta Januari s.d Mei tahun 2018}

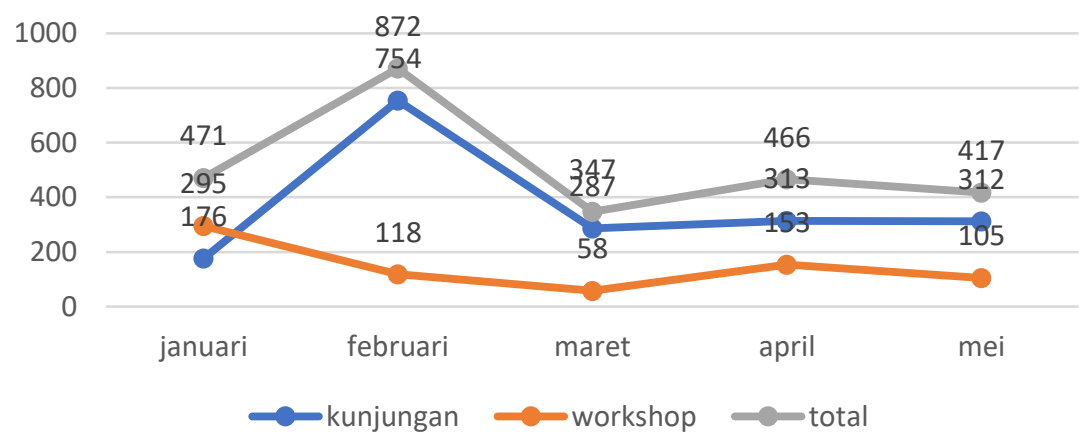

Sumber: Museum Batik Yogyakarta, 2018

Gambar 4 menjelaskan bahwa, pada semester awal tahun 2018 wisatawan yang mengunjungi museum tidak hanya sekedar melihat koleksi ataupun membeli batik yang tersedia di Museum Batik Yogyakarta. Namun, wisatawan juga mengikuti workshop atau pelatihan melukis batik klasik yang dijalankan oleh Museum Batik Yogyakarta.

Berdasarkan hasil pengamatan dan wawancara secara In-depth menunjukkan terdapat beberapa segmentasi pasar tertentu dari Museum Batik Yogyakarta. Assauri (2015) menjelaskan bahwa, segmentasi pasar dimaksud sebagai kegiatan membagi suatu pasar ke dalam kelompok-kelompok yang berbeda. Suatu usaha untuk mengelompokkan konsumen dalam beberapa kelompok yang secara relatif orang-orang nya cukup homogen (Ginting, Negara, \& Sudiarta, 2015). Berikut penjabarannya:

Tabel 1. Model Segmentasi Pasar Museum Batik Yogyakarta

No. Hasil Wawancara dan Observasi

76 Jurnal Kepariwisataan: Destinasi, Hospitalitas dan Perjalanan, Volume 4 Nomor 2, 2020: 72-83 


\begin{tabular}{ll}
\hline 1. & Demografis \\
\hline & 1) Wisatawan Usia Pendidikan dasar (TK, SD, SMA) bingga pendidikan tinggi (Master) \\
2) Pekerjaan dari wisatawan pelajar (pelajar asli maupun luar Daerah Istimewa Yogyakarta) \\
\hline 2. & Geografis \\
\hline 1) Wisatawan Nusantara dari kawasan Di Yogyakarta dan luar DI Yogyakarta (Indonesia) \\
2) Wisatawan Mancanegara (terdapat 5 bahasa dalam brosur) \\
\hline 3. Psikografis \\
1) Wisatawan yang ingin memperlajari budaya batik \\
2) Wisatawan yang ingin belanja batik \\
3) Wisatawan yang ingin belajar membatik melalui workshop batik klasik \\
4) Wisatawan kelas khusus yang memiliki minat terhadap batik eksklusif
\end{tabular}
Sumber: Data Diolah Penulis (2019)

Segmentasi Pasar Museum Batik Yogyakarta memunculkan beberapa segmen tertentu yang menjadi inti dari pemasaran yang sudah dijalankan oleh Museum Batik Yogyakarta. Pertama, Segmen pasar Museum Batik Yogyakarta didominasi oleh pelajar, baik pelajar asli Yogyakarta maupun yang berasal dari luar Yogyakarta. Selain itu wisatawan yang datang bukan hanya wisatawan nusantara namun, wisatawan mancanegara.

Hasil dari pemaparan segmentasi pasar tersebut juga menjelaskan bahwa Museum Batik Yogyakarta menjadikan koleksi batik dan produk batik menjadi salah satu jalan untuk melestarikan budaya lokal asli Indonesia. Museum batik yogyakarta dapat dikatakan sebagai pelopor dalam memasarkan produk dan jasanya sekaligus usaha dalam pelestarian batik. Berbagai inovasi telah dilakukan oleh berbagai pihak terkait dengan pelestarian budaya batik. Terkait motif batik yang ada di toko batik yang ada di Museum Batik Yogyakarta Bapak D menjelaskan bahwa:

"kain batik dasarnya memang digunakan untuk bawahan tapi seiring perkembangan jaman, banyak kain batik yang digunakan untuk atasan. Ini akhirnya menggeser makna bagi setiap motif kain" (D, Pemandu Wisata, 16 mei 2018).

Oleh karena itu, Produk yang dijual di toko batik milik Museum Batik Yogyakarta tidak mengabaikan pola jahit dan penempatan posisi dari batik itu sendiri. Hal tersebut menjelaskan bahwa, dalam mengelola produk batik jual tidak perlu menghilangkan makna dari motif batik.

\section{Identifikasi Bauran Pemasaran 7P Museum Batik Yogyakarta}

Berdasarkan hasil pengamatanan langsung dan wawancara secara in-depth terdapat paparan variabel-variabel 7P Bauran Pemasaran yang telah terimplementasi di Museum Batik Yogyakarta. Berikut Pemaparannya:

1. Product (Produk)

Produk merupakan segala sesuatu yang dapat ditawarkan ke pasar untuk mendapatkan perhatian, dibeli, dimiliki, digunakan, atau dikonsumsi yang dapat memuaskan keinginan atau kebutuhan pemakainya (Kotler \& Amstrong, 2007). Museum Batik Yogyakarta adalah museum yang memamerkan jenis-jenis koleksi batik yang dimiliki oleh bapak Hadi Nugroho dan ibu Dewi Sukaningsih. Ragam motif yang dimiliki oleh Museum Batik Yogyakarta adalah Jawa Tengahan (Yogyakarta dan Solo), pasisiran (Semarang, Demak, Pekalongan dan Kedungwuni, Cirebon dan Lasem), Madura, mBayat-Klaten, Kebumen, Kulon Progo, Imogiri, dan beberapa daerah lainnya. Selain itu, batik kontemporer yang mengkolaborasikan batik dengan berbagai otentisitas beberapa Negara juga menjadi koleksi dari Museum Batik Yogyakarta. Museum dibuka untuk umum sebagai pengabdian masyarakat dan sebagai tempat memberikan informasi dan konsultasi mengenai batik. Museum Batik adalah menyediakan koleksi tentang Batik milik Bapak Hadi dengan berbagai jenis dan 
asal batik yang bermacam-macam, Proses Pembuatan Batik, Berbagai Hasil Batik, Karya Istri Bapak Hadi dan sebagainya. Beberapa wisatawan yang menjadi segmen dari produk museum didominasi oleh pelajar, baik pelajar asli Yogyakarta maupun yang berasal dari luar Yogyakarta.

Untuk produk Batik yang dijual sebagai survenir dan pelatihan seperti batik cap dan batik tulis. Terdapat divisi yang mengayomi untuk segmen tertentu di Museum batik Yogyakarta, yakni Batik Inc. Divisi Museum Batik Yogyakarta yang secara kreatif mencipta desain batik yang mewah dan megah untuk perusahaan dan acara khusus. Tentunya ini menjadi segmen khusus yang dapat dikelola. Desain untuk batik tulis dan batik cap, pengadaan untuk perusahaan maupun instansi, aplikasi desain untuk acara khusus, pernikahan dan lain lain. Untuk pola batik diaplikasikan pada barang sehari-hari dalam acara tertentu atau atribut kantor. Hal ini menjadi peluang besar untuk melebarkan segmen pasar dari toko batik dari Museum batik Yogyakarta.

2. Price (Harga)

Price (harga) dapat juga diartikan penentuan nilai produk di benak konsumen (Nana, 2015; Nuryadin, 2007). Harga menjadi penting dikarenakan menjadi salah satu pertimbangan bagi wisatawan untuk mengunjungi sebuah destinasi. Pada tahun 2018, Harga tiket masuk di Museum Batik Yogyakarta adalah Rp. 20.000 per orang, baik untuk wisatawan nusantara ataupun wisatawan mancanegara. Dengan harga tersebut pengunjung mendapatkan fasilitas Pemandu yang akan memberikan informasi dan menerangkan barang-barang terdapat di museum tersebut. Selain itu, pengunjung juga dapat membeli batik dengan harga yang beragam, mulai dari harga Rp 300.000,sampai Rp 2.500.000, Pengelola Museum Batik Yogyakarta juga menyediakan fasilitas untuk workshop dan pelatihan membatik dengan biaya 40.000 perjam. Terdapat paket pelatihan membatik dan kunjungan dengan biaya Rp. 85.000 sampai Rp. 95.000.

\section{Promotion (Promosi)}

Promosi adalah kegiatan mengkomunikasikan informasi dari penjual kepada konsumen atau pihak lain dalam saluran penjualan untuk mempengaruhi sikap dan perilaku. Melalui periklanan suatu perusahaan mengarahkan komunikasi persuasif pada pembeli sasaran dan masyarakat melalui media-media yang disebut dengan media massa seperti koran, majalah, tabloid, radio, televisi,dan direct mail (Lukitaningsih, 2013). Promosi yang dilakukan oleh pengelola Museum Batik Yogyakarta melalui website di www.museumbatik.com dan instagram di @museumbatikyogyakartaofficial. Kemudian, adanya repost review terkait museum dari beberapa akun media sosial instagram seperti dari @travelokaexperience.

Selain itu, Museum Batik Yogyakarta ikut berkontribusi dalam acara-acara yang berkaitan dengan batik pada skala nasional maupun internasional. Berdasarkan hasil wawancara, wisatawan mancanegara atau nusantara memiliki peminatan tinggi terhadap batik kontemporer. Segmen tersebut menjadi target promosi dari Museum Batik Yogyakarta. Wisatawan mancanegara yang memiliki minat tinggi terhadap produk batik museum menjadi salah satu target utama, Hal ini dibuktikan dengan brosur yang berisi 5 jenis bahasa.

4. Place (Tempat)

Komponen yang menyangkut lokasi meliputi: pemilihan lokasi yang startegis (mudah dijangkau), di daerah sekitar pusat perbelanjaan, dekat dengan pemukiman penduduk, aman dan nyaman bagi pelanggan, adanya fasilitas yang mendukung dan lain-lain. Museum Batik Yogyakarta dulunya merupakan rumah dari bapak Hadi yang juga digunakan sebagai pabrik yang memproduksi batik. Sejak tahun 1979, bapak Hadi dan istri telah melestarikan dan mebuka galeri batik yang bisa dinikmati oleh masyarakat melalui destinasi museum. Museum batik terletak di pusat kota Yogyakarta, berada di area strategis. Letaknya berdekatan dengan pemukiman dan stasiun kereta api Lempuyangan. Di halaman depan museum terdapat beberapa pohon yang dapat digunakan untuk 
berteduh para wisatawan ketika mengunjungi museum di siang hari. Selain Museum itu sendiri, toko batik dan hotel menjadi magnet penting dalam bauran pemasaran Museum Batik Yogyakarta.

5. Physical Evidence (Fisik)

Bukti fisik menurut Kotler (2009), yaitu bukti yang dimiliki oleh penyedia jasa yang ditujukkan kepada konsumen sebagai usulan nilai tambah konsumen. Ketika wisatawan mengunjungi Museum Batik Yogyakarta, mereka akan melihat sebuah bangunan berbentuk rumah dengan halaman yang luas, bukan seperti museum pada umumnya. Museum menampilkan berbagai produk batik khas Indonesia dan beberapa produk kontemporer. Karyawan menggunakan batik sebagai atribut dari Museum. Di pintu depan, wisatawan akan disambut oleh resepsionis yang sekaligus melayani penjualan tiket masuk museum. Kegiatan workshop membatik yang sering dilakukan di dalam atau diluar museum menunjukkan atribut dan kekuatan dari edukasi yang ditawarkan oleh museum di dalam pelestarian batik itu sendiri.

6. People (Orang)

People (Orang) yang berinteraksi langsung dengan konsumen dalam memberikan jasa, merupakan bagian penting untuk membangun loyalitas. Pengetahuan dan kemampuan people (Orang) yang bekerja sesuai dengan tujuan perusahaan merupakan modal yang sangat penting untuk mencapai keberhasilan (Widyawati, 2018). Orang berkaitan dengan koordinasi pekerjaan penting di destinasi. Berdasarkan hasil pengamatan di tahun 2018, Jumlah karyawan di museum saat ini terdiri atas : satu orang pada manajemen museum, satu orang bagian keuangan, tiga orang bagian toko (kepala toko, keuangan, dasn pameran), tiga orang bagian produksi, dan dua orang pemandu museum.

7. Process (Proses)

Proses menggambarkan metode dan urutan layanan dan menciptakan nilai yang dijanjikan kepada pelanggan dengan cara melayani permintaan pelanggan (Kushwaha \& Agrawal, 2015). Senyum, sapa, dan salam menjadi hal yang wajib bagi seluruh karyawan Museum Batik Yogyakarta, Berdasarkan hasil wawancara, terkait rekrutmen karyawan prosesnya hampir sama dengan proses rekrutmen pada umumnya. Apabila terdapat pengajuan lamaran kerja dari masyarakat, akan dilihat kemampuannya. Setelah itu dilakukan pelatihan selama beberapa bulan. Jika sesuai dengan kebutuhan dan masuk kriteria maka akan direkrut sebagai karyawan. Salah satunya pelibatan mahasiswa sebagai pemandu wisata. Terkait workshop, Museum telah melibatkan karyawan yang mumpuni soal batik cap dan tulis.

\section{Analisis 7P Museum Batik Yogyakarta}

Konsep 7P Bauran Pemasaran dari Museum Batik Yogyakarta memaparkan kelebihan dan kekurangan pada aspek product (produk), price (harga), place (tempat), promotion (promosi), people (partisipan), physical evidence (bukti fisik), dan process (proses). Berikut merupakan hasil analisisnya:

1. Terkait Produk dan jasa, terdapat tempat proses pelatihan pembuatan batik tulis yang sebenarnya menjadi magnet untuk wisatawan yang memiliki minat khusus terkait batik. Terutama workshop membatik pada batik cap maupun batik tulis. Berdasarkan hasil studi literature, beberapa wisatawan mancanegara yang mengikuti workshop ini berasal dari Thailand, Amerika, Inggris, dan Jerman. Untuk Koleksi batik di Museum, secara pengamatan langsung dari penulis terdapat beberapa kekurangan dalam penataan dan kerapian. Beberapa batik yang disimpan terkesan kurang teratur penataannya. Selain koleksi, Beberapa produk batik yang dijual perlu pengembangan lebih lanjut dalam keberlanjutan batik itu sendiri. Terutama batik kontemporer yang perlu memiliki diversifikasi produk pada segmen anak-anak hingga dewasa. Melihat Segmen dari perusahaan diperlukan penguatan pengelolaan produk pada segmen pasar yang dikelola produksinya oleh divisi Batik inc. 
2. Untuk Harga, terdapat penyamaan harga untuk wisatawan mancanegara dan nusantara. Menurut Sukotjo (2010) harga dikatakan mahal, murah atau biasa-biasa saja dari setiap individu tidaklah harus sama, karena tergantung dari persepsi individu yang dilatar belakangi oleh lingkungan kehidupan dan kondisi individu. Seharusnya ini perlu dipertimbangkan terkait keberlanjutan dari museum sendiri. Seharusnya untuk wisatawan mancanegara diberikan harga yang lebih tinggi. Penerapan ini seharusnya dijalankan untuk rombongan wisatawan mancanegara yang datang ke museum. Namun, untuk harga produk batik dan workshop training membatik untuk rombongan wisatawan dapat disesuaikan pada selera wisatawan.

3. Dalam kegiatan Promosi, Museum Batik Yogyakarta telah ikut mempromosikan produknya dan koleksinya melalui berbagai event. Hal ini perlu ditindak lanjuti oleh generasi-genarasi berikutnya pada pengelola. Untuk promosi daring, terdapat media sosial dan website. Namun konten yang ditampilkan cenderung kurang konsisten di tahun 2018. Untuk saat ini sudah bertambah akun @sourvenirshopmuseumbatik yang menjual secara daring produk dari toko yang disediakan oleh Museum Batik Yogyakarta. Akun penjualan ini menampilkan produk batik melalui sosial media instagram. Hal ini menunjukkan bahwa pengelola sudah mulai melakukan promosi secara daring dengan sosial media Instagram, baik untuk Museumnya maupun toko batiknya. Kemudian, melaksanakan kegiatan workshop di beberapa institusi. Workshop tersebut secara tidak langsung ikut mempromosikan Museum Batik Yogyakarta sebagai salah satu destinasi yang melakukan pelestarian budaya.

4. Kushwaha dan Agrawal (2015) menjelaskan bahwa keputusan untuk pendistribusian secara fisik dipertimbangkan dari bagaimana pesanannya diproses, letak tempat penyimpanan, seberapa siap barang yang ditawarkan, dan bagaimana barang disalurkan. Museum Batik Yogyakarta memiliki letak yang sangat strategis. Hal ini sangat menguntungkan dikarenakan menjadi sangat penting terkait konektifitas di google maps dan pemasaran melalui media sosial.

5. Keadaan fisik dijelaskan sebagai situasi lingkungan dimana pelayanan dirasakan langsung oleh konsumen, beserta semua komponen yang mendukung realisasi atau komunikasi dari pelayanan di tempat itu (Naibaho, Fauzi, \& Sadalia, 2020). Secara fisik, tempat ini sangatlah unik dan sedikit tertata dengan sederhana dan baik. Pemandu dan karyawan memakai batik sesuai dengan identitas utama dari produk budaya yang ditawarkan oleh museum. Atribut yang dipakai oleh pengelola maupun karyawan magang menunjukkan identitas museum, yakni batik. pengelola perlu memanfaatkan promosi melalui maksimalisasi media sosial, terutama untuk produk batik jual.

6. Pengunjung atau wisatawan yang memasuki museum, akan disambut resepsionis yang merangkap sebagai tempat penjualan tiket. Pemandu bertugas menerangkan secara rinci tentang segala hal menyangkut museum. Pemandu memberikan kesempatan untuk mengambil gambar. terdapat bagian mana saja yang tidak boleh diambil gambarnya. Program workshop membatik juga ditawarkan oleh pihak museum. Hal ini menunjukkan setiap orang memiliki peran di dalam Museum, dan menjalankan secara baik. Walaupun, dalam prakteknya terdapat rangkap tugas saat di resepsionis. Untuk kedepannya dibutuhkan sesuatu yang dapat mengkoordinasikan tugas secara efisien dan tepat guna. Pengetahuan dan kemampuan people yang bekerja sesuai dengan tujuan perusahaan merupakan modal yang sangat penting untuk mencapai keberhasilan.

7. Terkait proses, Museum Batik Yogyakarta juga menerima mahasiswa yang ingin melakukan PKL (Prkaktek Kerja Lapangan). Namun berdasarkan hasil pengamatan, menunjukkan kurang cekatannya para pemandu yang berstatus PKL. Menurut Kotler (2009), proses disini adalah mencakup bagaimana cara perusahaan melayani permintaan tiap konsumennya. Hal ini menunjukkan bahwa, dalam proses diperlukan proses transfer ilmu dan nilai dari pemandu terhadap wisatawan. Perlu dilakukan koordinasi secara lebih baik untuk pemandu yang 
melaksanakan PKL di waktu yang akan datang. Namun untuk pelatih workshop merupakan orangorang yang ahli di bidangnya. Sehingga, tidak salah bila banyak wisatawan mancanegara yang nyaman dengan proses pelatihan batik cap maupun tulis.

\section{Strategi Alternatif Pemasaran Museum Batik Yogyakarta}

Berdasarkan hasil analisis terkait bauran pemasaran 7P Terdapat beberapa hal yang dapat direkomendasikan sebagai strategi alternatif pemasaran untuk Museum Batik Yogyakarta. Berikut penjelasannya:

1. Penguatan nilai sejarah dan budaya sebagai identitas produk dari batik di museum. Untuk batik, diperlukan pembenahan dan pengelolaan produk yang diharapkan semakin meningkatkan nilai dari batik itu sendiri. Wisatawan akan mendapatkan pengalaman lebih melalui kegiatan belajar membatik. Pengalaman membatik sendiri inilah yang menjadi suguhan unik sehingga banyak pengunjung yang penasaran dan ingin mencoba (Kustiyah, 2017). Selain itu, Packaging atau pengemasan produk dalam konteks branding Museum Batik Yogyakarta menjadi penting untuk dikaji lebih dalam mengenai produk budaya ini. Terutama batik-batik kontemporer yang ada di museum. Walaupun secara produk sudah sangat unik dan baik, pengelolaan toko dan workshop perlu pengembangan serius. Hal ini terkait program jangka panjang dari Museum Batik Yogyakarta dalam keberlanjutan batik itu sendiri. Tentang segmentasi pasar dari wisatawan di masa yang akan datang. Oleh karena itu variasi produk perlu ditingkatkan. Terutama di produk batik kontemporer.

2. Diferensiasi harga pada tiket masuk untuk wisatawan. Harga memang menjadi salah satu bentuk bauran pemasaran yang bisa menghasilkan pendapatan, akan tetapi harga yang yang ditetapkan harus sesuai dengan segmen pasar yang ditentukan (Murti, 2017). Oleh karena itu, sudah seharusnya museum membedakan harga untuk wisatawan asing dengan wisatawan nusantara. Selain dapat meningkatkan kunjungan, juga memungkinkan dapat menaikkan sisi eksklusifitas dari museum dan batik itu sendiri. terdapat pengadaan workshop dan pelatihan untuk wisatawan yang datang secara rombongan dan berasal dari instansi-instansi seperti kementrian pariwisata, dinas kebudayaan, dan lain-lain. harusnya diberikan paket-paket tertentu yang juga diberlakukan untuk wisatawan mancanegara dan nusantara.

3. Optimalisasi kekuatan daring melalui media sosial. Faktanya, Museum telah menjadi destinasi yang stabil, namun melihat kemajuan zaman yang semakin pesat tentu proses pengelolaan media sosial dan website. Di era modern seperti saat ini website serta media sosial sangat bermanfaat utamanya untuk promosi, media informasi, serta sebagai media komunikasi (Pratiwi \& Khoirunisaa, 2018) Pemasaran online memegang peranan penting dalam meningkatkan segala aspek pemasaran, baik dari segi promosi maupun penjualan (Triono \& Sari, 2017). Walaupun sudah berjalan melalui media sosial untuk penjualan survenir, perlu didalami pengembangan pengelolaannya. Selain itu, konsistensi keikutsertaan dalam event-event nasional maupun internasional perlu dimaksimalkan agar dapat membantu proses promosi.

4. Optimalisasi tugas dan pekerjaan pada Sumber daya Manusia. Manajemen museum batik perlu lebih cermat dalam koordinasi tugas di dalam pengelolaan. Terutama pengelolaan untuk website dan sosial media. Hal ini terkait dengan program jangka panjang untuk Museum. Untuk pemandu, perlu diberikan pembekalan lebih serius mengenai sejarah dari apa yang di representasikan kepada wisatawan mengenai sejarah dan nilai budaya dari produk museum. Hal ini penting untuk dijalankan, walaupun karyawan tersebut berstatus PKL atau magang. Selanjutnya untuk pengarah atau pelatih dalam sesi workshop perlu diberikan pengelolaan treatment lebih. Hal ini agar keberlanjutan dari proses membatik dan pelestarian budaya membatik terus berlanjut.

\section{SIMPULAN}


Berdasarkan hasil dan pembahasan diatas, Untuk mempertahankan eksistensi keberadaan Museum Batik Yogyakarta, perlu dilakukan implementasi strategi bauran pemasaran yang berasal dari analisis terhadap aspek 7P, yaitu: product (produk), price (harga), place (tempat), promotion (promosi), people (orang), physical evidence (bukti fisik), dan process (proses). Strategi Alternatif yang dapat dijalankan oleh Pengelola Museum Batik Yogyakarta dihasilkan dari beberapa modifikasi hasil analisis terhadap berbagai aspek 7P. Bebrapa rekomendasi strategi yang disarankan adalah Penguatan nilai sejarah dan budaya sebagai identitas produk dari batik dan museum, Diferensiasi harga pada tiket masuk untuk wisatawan, Optimalisasi kekuatan daring melalui media sosial, dan Optimalisasi tugas dan pekerjaan pada Sumber daya Manusia. Keempat alternatif poin strategi tersebut dirasa penting. Hal ini mengingat bahwa destinasi yang mengunggulkan nilai budaya sebagai produk mereka membutuhkan keseriusan dalam kaitan koordinasi dalam sumber daya manusia dan penguatan kearifan lokal dalam sebuah produk wisata.

Penelitian ini masih memiliki beberapa kekurangan. Diperlukan penelitian lanjutan yang mengambil sisi kuantitatif baik dari segi keuangan, perilaku wisatawan, dan segmen pasar. Hal tersebut, nantinya dapat dijadikan bahan literasi pendukung dalam pengembangan keberlanjutan dari batik dan kepengelolaan Museum Batik Yogyakarta itu sendiri.

\section{DAFTAR REFERENSI}

Abdullah, M. (2015). Metodologi Penelitian Kuantitatif. Yogyakarta: Aswaja Pressindo.

Agic, E., Cinjarevic, M., Kurtovic, E., \& Cicic, M. (2016). Strategic marketing patterns and performance implications. European Journal of Marketing, 50(12), 2216-2248. https://doi.org/10.1108/ejm-08-2015-0589

Asmara, D. (2019). Peran Museum dalam Pembelajaran Sejarah. Kaganga:Jurnal Pendidikan Sejarah Dan Riset Sosial-Humaniora, 2(1), 10-20. https://doi.org/10.31539/kaganga.v2i1.707

Assauri, S. (2015). Manajemen Pemasaran. Jakarta: Rajawali Pers.

Bogdan, R. C., \& Biklen, S. K. (1982). Qualitative Research for Education: An Introduction to Theory and Methods. Boston: Allyn and Bacon, Inc.

Ginting, M. S. B., Negara, I. M. K., \& Sudiarta, I. N. (2015). Analisis Segmentasi Pasar Wisatawan Mancanegara yang Berkunjung ke bali dari Aspek Sosio-Ekonomi Demografi, Psikografi, dan Perilaku. Jurnal IPTA, 3(2), 98. https://doi.org/10.24843/ipta.2015.v03.i02.p17

Harrington, R. J., Ottenbacher, M. C., \& Fauser, S. (2017). QSR brand value. International Journal of Contemporary Hospitality Management, 29(1), 551-570. https://doi.org/10.1108/ijchm06-2015-0300

Kamal-Chaoui, L. (2019). Culture and Local Development: Maximasing the Impact. Organization for Economic Co-operation and Development and International Council of Museums. Venezia: ICOM.

Karimah, F. U., Ernawati, E., \& Andreswari, D. (2015). Rancang Bangun Aplikasi Pencarian Citra Batik Besurek Berbasis Tekstur dengan Metode Gray Level Co-occurrence Matrix dan Euclidean Distance. Cyberku Journal, 11(1), 64-77.

Kotler, P. (2009). Manajemen pemasaran. Jakarta: Erlangga.

Kotler, P., \& Amstrong, G. (2007). The principles of marketing. New Jersey: Prentice Hall Publishing.

Kushwaha, G. S., \& Agrawal, S. R. (2015). An Indian customer surrounding 7P' s of service marketing. Journal of Retailing and Consumer Services, 22, 85-95.

Kustiyah, I. E. (2017). Batik sebagai identitas kultural bangsa Indonesia di era globalisasi. Gema, $30(52), 62476$.

Lukitaningsih, A. (2013). Iklan Yang Efektif Sebagai Strategi Komunikasi Pemasaran. Jurnal Ekonomi Dan Kewirausahaan, 13(2), 116-129. 
Miles, M. B., \& Huberman, A. M. (1992). Analisis Data Kualitatif: Buku Sumber Tentang Metode Metode Baru. Jakarta: UI Press.

Mudzanani, T. E. (2017). The four 'C's of museum marketing: Proposing marketing mix guidelines for museums. Afr. J. Hosp. Tour. Leis, 6, 1-12.

Muftisany, H. (2012). Berkunjung Yuk ke Museum Batik Yogyakarta. Retrieved April 4, 2020, from Republika.co,id website: https://www.republika.co.id/berita/senggang/senibudaya/12/10/02/mb94hq-berkunjung-yuk-ke-museum-batik-yogyakarta

Murti, A. B. (2017). Strategi Komunikasi Pemasaran Museum Gunungapi Merapi dan Museum Affandi Yogyakarta dalam Meningkatkan Jumlah Pengunjung. Universitas Islam Indonesia.

Museum Batik. (2020). Profil Museum Batik. Retrieved May 28, 2020, from Museum Batik website: https://www.museumbatik.com/page/Profil.html

Naibaho, E. R., Fauzi, A., \& Sadalia, I. (2020). The Effect of Marketing Mix on Satisfaction of Customer Insurance Products Unit Link (Empirical Study in PT AIA Financial Branch Phoenix Medan). International Journal of Research and Review, 7(2), 47-55.

Nana, H. A. (2015). Manajemen Strategi Pemasaran. Bandung: Pustaka Setia.

Nuryadin, M. B. (2007). Harga dalam Perspektif Islam. Jurnal Ekonomi Islam: Mazahib, 4(1), 8698.

Oematan, F. (2017). Analisis Bauran Pemasaran di Hotel Sasando Kupang. Agora, 5(2).

Prapannetivuth, A. (2015). The Marketing Mix in Small Sized Hotels: A Case of Pattaya, Thailand. International Journal of Social, Behavioral, Educational, Economic, Business and Industrial Engineering, 9(11), 3903-3906.

Pratiwi, M. L., \& Khoirunisaa, N. (2018). Pengembangan Objek Museum Keris di Kota Surakarta. Slamet Riyadi Conference on Public Administration (SRIPA).

Sadq, Z. M., Othman, B., \& Khorsheed, R. K. (2019). The impact of tourism marketing in enhancing competitive capabilities. African Journal of Hospitality, Tourism and Leisure, 8(5), 1-11.

Sahidah, B. A., \& Habsari, N. T. (2018). Eksistensi Batik Pecel (Sejarah, Makna Simbolis Dan Potensinya Sebagai Ikon Pariwisata Kota Madiun). Agastya: Jurnal Sejarah Dan Pembelajarannya, 8(2), 221-238.

Sara, E. M. D., Ernawati, E., \& Johar, A. (2019). Implementasi Metode Point Minutiae Untuk Mengidentifikasi Jenis Batik Pada Batik Besurek Dengan Berbasis Tekstur. Rekursif: Jurnal Informatika, 7(1).

Sugiyono. (2008). Metode Penelitian Kualitatif dan R\&D. Bandung: Alfabeta.

Sukotjo, H., \& Radix, S. A. (2010). Analisa Marketing Mix-7P (Produk, Price, Promotion, Place, Partisipant, Process, dan Physical Evidence) terhadap Keputusan Pembelian Produk Klinik Kecantikan Teta di Surabaya. Jurnal Mitra Ekonomi Dan Manajemen Bisnis, 1(2), 216-228.

Travers, T., \& Glaister, S. (2004). Valuing museums: Impact and innovation among national museums. National Museum Directors' Conference, Imperial War Museum.

Triono, B. R. M. S., \& Sari, C. T. (2017). Efektivitas Strategi Pemasaran Online bagi Museum Kraton Kasunanan Surakarta. Wasana Nyata, 1(2), 14-20.

Wardiyanta, W., Sudarmadji, S., \& Nopirin, N. (2016). Studi Eksploratif Mengenai Yogyakarta sebagai Pengirim Wisatawan Keluarga. Jurnal Ilmu Sosial Dan Ilmu Politik, 20(1), 84-96.

Widyawati, N. (2018). Pengaruh Kepercayaan dan Komitmen serta bauran Pemasaran Jasa Terhadap Loyalitas Konsumen Di Hotel Zakiah Medan. EKUITAS Uurnal Ekonomi Dan Keuangan), 12(1), 74-96. 